\title{
Diabrotica-resistant Bt-maize DKc5143 event MON88017 has no impact on the field densities of the leafhopper Zyginidia scutellaris
}

\author{
Stefan RAUSCHEN ${ }^{1 *}$, Eva SCHULTHEIS ${ }^{1}$, Heinz HUNFELD ${ }^{2}$, Frank SCHAARSCHMIDT ${ }^{3}$, Ingolf SCHUPHAN ${ }^{4}$ and Sabine EBER ${ }^{1}$ \\ 1 RWTH Aachen University, Department of Plant Physiology (Biology III), Worringerweg 1, 52074 Aachen, Germany \\ 2 Institute for Applied Biotechnology in the Tropics at the University of Göttingen, 37077 Göttingen, Germany \\ ${ }^{3}$ Leibniz Universität Hannover, Faculty of Natural Sciences, Institute of Biostatistics, Herrenhaeuser Straße 2, 30419 Hannover, Germany \\ ${ }^{4}$ RWTH Aachen University, Institute of Environmental Research (Biology V), Worringerweg 1, 52074 Aachen, Germany
}

Auchenorrhyncha (planthoppers and leafhoppers) are herbivorous organisms that can ingest Cry proteins from genetically engineered Bt-crops depending on their feeding behaviour. Consequently, they might be directly affected by non-target Bt-protein action and more importantly serve as a source of Cry protein exposure to beneficial predatory arthropods. During a three year field study, we surveyed the community of Auchenorrhyncha in Diabrotica-resistant Bt-maize DKc5143-Bt (event MON88017), its near-isogenic line and two conventional hybrids using sweep netting and custom made sticky traps. Zyginidia scutellaris (Herrich-Schäffer) (Hemiptera: Cicadellidae) represented more than $60 \%$ of all captured individuals, indicating that it is the dominant leafhopper within the maize community. The statistical analysis of $Z$. scutellaris data using confidence intervals for the ratios of mean abundance showed no consistent differences between the Bt-maize and the near-isogenic cultivar, indicating no negative impact of event MON88017. The two conventional hybrids Benicia and DK315 exhibited differences in terms of $Z$. scutellaris densities, which were greater than those observed between MON88017 and the near-isogenic line, but also not consistent over the years. Six more species accounted for an additional $39 \%$ of all captured specimens, while ten more species were found only as single individuals and can be considered vagrants from neighbouring habitats. These results inform future field work on the non-target impact of Bt-maize on this group of arthropods and monitoring approaches to assess biological control function by surveying herbivore communities.

Keywords: Bt-maize / environmental risk assessment / MON88017 / non-target organisms / Zyginidia scutellaris

\section{INTRODUCTION}

One of the major traits used in genetically engineered (GE) crops today is insect pest resistance based on the expression of proteins derived from Bacillus thuringiensis (Berliner). This ubiquitous soil bacterium forms crystalline protein inclusion bodies upon sporulation, which are toxic to specific taxa of insects (Glare and O’Callaghan, 2000; Schnepf et al., 1998). Until now, crops have been introduced that express Lepidopteran specific Cry1 and Cry2 proteins or Coleopteran specific Cry3 proteins. The two most important crops on which this technology has been used are maize and cotton, with an increase in recent years in acreage planted to so called "stacked" varieties combining both resistances (James, 2009). In Europe, only Bt-maize hybrids resistant against

* Corresponding author:

Rauschen@Bio3.RWTH-Aachen.de the European corn borer Ostrinia nubilalis (Hübner) (Lepidoptera: Crambidae) and Mediterranean corn borer Sesamia nonagrioides (Lefebvre) (Lep.: Noctuidae) by expression of Cry $1 \mathrm{Ab}$ have been cultivated so far. A new trait provided by the $B t$-technology for the European market is resistance to the Western corn rootworm Diabrotica virgifera virgifera (LeConte) (Coleoptera: Chrysomelidae). This pest was accidentally introduced to Europe from the United States approximately twenty years ago and is regarded as a serious threat to European maize yields (Hummel, 2003; Kiss et al., 2005; Miller et al., 2005). Resistance of plants to D. virgifera virgifera is conferred by the expression of different $B t$-proteins, such as Cry3Bb1, Cry34Ab1 and Cry35Ab1, or a modified Cry3A.

A pre-market risk assessment of GE crops is mandatory under European Union (EU) legislation. Additionally, the directive 2001/18/EC stipulates a monitoring 


\section{S. Rauschen et al.}

plan for the post-market surveillance of the possible environmental effects of the large scale commercial cultivation of these crops (EFSA, 2006; EU, 2001, 2002). Monitoring schemes comprise the hypothesis-driven Case Specific Monitoring as well as the General Surveillance. The former serves to fill knowledge gaps on identified risks pertaining to specific aspects of the previous risk assessment (e.g. baseline susceptibility of the target pest, possibility of resistance development), while the latter focuses on possible adverse effects not foreseen in the environmental risk assessment, and on long-term, cumulative and indirect effects (Sanvido et al., 2005). There is consensus among many scientists that the focus of premarket regulatory assessment should be on organisms (i) exposed to a specific Bt-crop's toxin because of their association with the host plant, and/or (ii) serving important ecological and anthropogenically valued functions, such as biological control of agricultural pests (Romeis et al., 2008). The nature of the association with the plant can either be herbivorous or predacious. The extent of exposure of a given species to a Cry protein then depends on the respective pathway (i.e. by directly feeding on plant tissue, or via the consumption of herbivorous insects which have previously been exposed, Romeis et al., 2006).

Auchenorrhyncha (planthoppers and leafhoppers) are diverse and highly abundant in maize fields (Kiss et al., 2002; Rauschen et al., 2008; Schmitz and Bartsch, 2001), with the maize leafhopper Zyginidia scutellaris (HerrichSchäffer) being the most abundant leafhopper (Candolfi et al., 2004; Pons et al., 2005; Rauschen et al., 2008) and having a close tie to maize (Nickel, 2003). Depending on the mode of feeding (Nickel, 2003) exposure to Cry proteins from genetically engineered $B t$-maize can be assumed for a variety of species and has been substantiated for the mesophyll feeding Z. scutellaris (Dutton et al., 2004; Meissle and Romeis, 2009; Obrist et al., 2006). Auchenorrhyncha fall prey to generalist predators, such as spiders (Árpás et al., 2005; Meissle and Romeis, 2009), and to specialised parasitoids (Nickel, 2003). They could therefore be used indirectly to assess the status of the biological control function of predatory arthropods in $B t$-maize, but they have not yet been considered for that purpose (Sanvido et al., 2009).

We investigated the impact of Diabrotica-resistant Btmaize MON88017 on the Auchenorrhyncha assemblage in general and the field densities of the maize leafhopper in particular. This was done to inform field approaches to Environmental Risk Assessments of these arthropods, and to gather data that could also inform the development and design of monitoring approaches in General Surveillance. To this end, the abundances of Auchenorrhyncha were compared between the Bt-maize DKc5143Bt (event MON88017), the near-isogenic line and two conventional hybrids with sweep nets and custom made sticky traps. These two methods had previously been evaluated and recommended for this purpose (Rauschen et al., 2008).

\section{RESULTS}

\section{General overview}

The Auchenorrhyncha assemblage at the experimental site consisted of five species from the planthopper family Delphacidae and 12 species from the two leafhopper families Aphrophoridae and Cicadellidae (Tab. 1). Phloem is the predominant resource utilised. Only leafhoppers from either the family Aphrophoridae or the Typhlocybinae subgroup of the family Cicadellidae feed on xylem and mesophyll, respectively. Various grasses are the host plants for most of these species, with Z. scutellaris, L. striatella and J. pellucida being the only species for which maize is expressly given as a host.

In total, 10474 individual insects were caught over the three experimental years. $99.3 \%$ of these specimens belong to only seven different species: Z. scutellaris (6746 individuals; 64.4\%), P. alienus (956; 9.1\%), J. pellucida $(638 ; 6.1 \%)$, E. atropunctata $(576 ; 5.5 \%)$, E. pteridis $(531 ; 5.1 \%)$, M. laevis $(527 ; 5.0 \%)$ and L. striatella $(430 ; 4.1 \%)$. The other 10 species combined accounted for 70 individuals $(0.7 \%)$. Only the maize leafhopper Z. scutellaris was present in numbers high enough for a robust statistical analysis. Therefore, only the results for the maize leafhopper are discussed in more detail.

\section{Abundance of $Z$. scutellaris over the growing season}

There was an increase in the density of the maize leafhopper over the growing seasons of the first two years based on the data obtained with the sweep netting (Tab. 2). In 2005, the densities increased in all maize hybrids 6-fold at average from July to August, while in 2006 there was increase from 4- to 7-fold, depending on the variety, from July to September. In 2007, however, this increase could not be observed. Conversely, the population densities decreased over the growing season from a high level in July, reaching only a fraction of that level in September.

The sticky traps in general showed a converse pattern to the sweep netting, with most insects caught early in the season and lower densities at later sampling dates. In July, more Z. scutellaris were caught with sticky traps, whereas in August and September the sweep netting yielded more individuals. This pattern was not observed in 2007 when fewer leafhoppers could be caught with the sticky traps than with the sweep nets at all sampling dates. 
No impact of Bt-maize MON88017 on Zyginidia scutellaris densities

Table 1. Systematic overview of the Auchenorrhyncha species assemblage found in maize at the experimental site, with the utilised plant substrates and host plants according to Nickel (2003).

\begin{tabular}{|c|c|c|c|c|}
\hline Suborder & Family (Subfamily) & Species & Feeding on & Host plants \\
\hline $\begin{array}{l}\text { Fulgoromorpha } \\
\text { (planthoppers) }\end{array}$ & Delphacidae & $\begin{array}{c}\text { Laodelphax striatella (Fall.) } \\
\text { Javesella pellucida (F.) } \\
\text { Dicranotropis hamata (Boh.) } \\
\text { Ribautodelphax albostriata (Fieb.) } \\
\text { Megadelphax sordidula (Stal) }\end{array}$ & $\begin{array}{l}\text { phloem } \\
\text { phloem } \\
\text { phloem } \\
\text { phloem } \\
\text { phloem }\end{array}$ & $\begin{array}{l}\text { grasses, maize } \\
\text { grasses, maize } \\
\text { grasses } \\
\text { Poa } \\
\text { Arrhenatherum }\end{array}$ \\
\hline \multirow[t]{4}{*}{$\begin{array}{l}\text { Cicadomorpha } \\
\text { (leafhoppers) }\end{array}$} & Aphrophoridae & $\begin{array}{c}\text { Philaenus spumarius (L.) } \\
\text { Neophilaenus campestris (Fall.) }\end{array}$ & $\begin{array}{l}\text { xylem } \\
\text { xylem }\end{array}$ & $\begin{array}{l}\text { herbs } \\
\text { grasses }\end{array}$ \\
\hline & $\begin{array}{l}\text { Cicadellidae } \\
\text { (Aphrodinae) }\end{array}$ & Anoscopus albifrons (L.) & phloem & grasses \\
\hline & (Typhlocybinae) & $\begin{array}{c}\text { Zyginidia scutellaris (H.-S.) } \\
\text { Empoasca pteridis (Dhb.) } \\
\text { Eupteryx atropunctata (Goeze) }\end{array}$ & $\begin{array}{l}\text { mesophyll } \\
\text { mesophyll } \\
\text { mesophyll }\end{array}$ & $\begin{array}{c}\text { grasses, maize } \\
\text { herbs } \\
\text { Lamiaceae }\end{array}$ \\
\hline & (Deltocephalinae) & $\begin{array}{c}\text { Psammotettix alienus (Dhb.) } \\
\text { Macrosteles laevis (Rib.) } \\
\text { Hardya tenuis (Germ.) } \\
\text { Euscelidius variegatus (Kbm.) } \\
\text { Artianus interstitialis (Germ.) } \\
\text { Balclutha punctata (F.) }\end{array}$ & $\begin{array}{l}\text { phloem } \\
\text { phloem } \\
\text { phloem } \\
\text { phloem } \\
\text { phloem } \\
\text { phloem }\end{array}$ & $\begin{array}{l}\text { grasses } \\
\text { grasses, herbs } \\
\text { grasses } \\
\text { unknown } \\
\text { grasses } \\
\text { grasses, trees }\end{array}$ \\
\hline
\end{tabular}

Table 2. Numbers of female and male Z. scutellaris caught with sweep nets and sticky traps at the different sampling dates pooled over all maize hybrids, and percent fractions of total individuals caught.

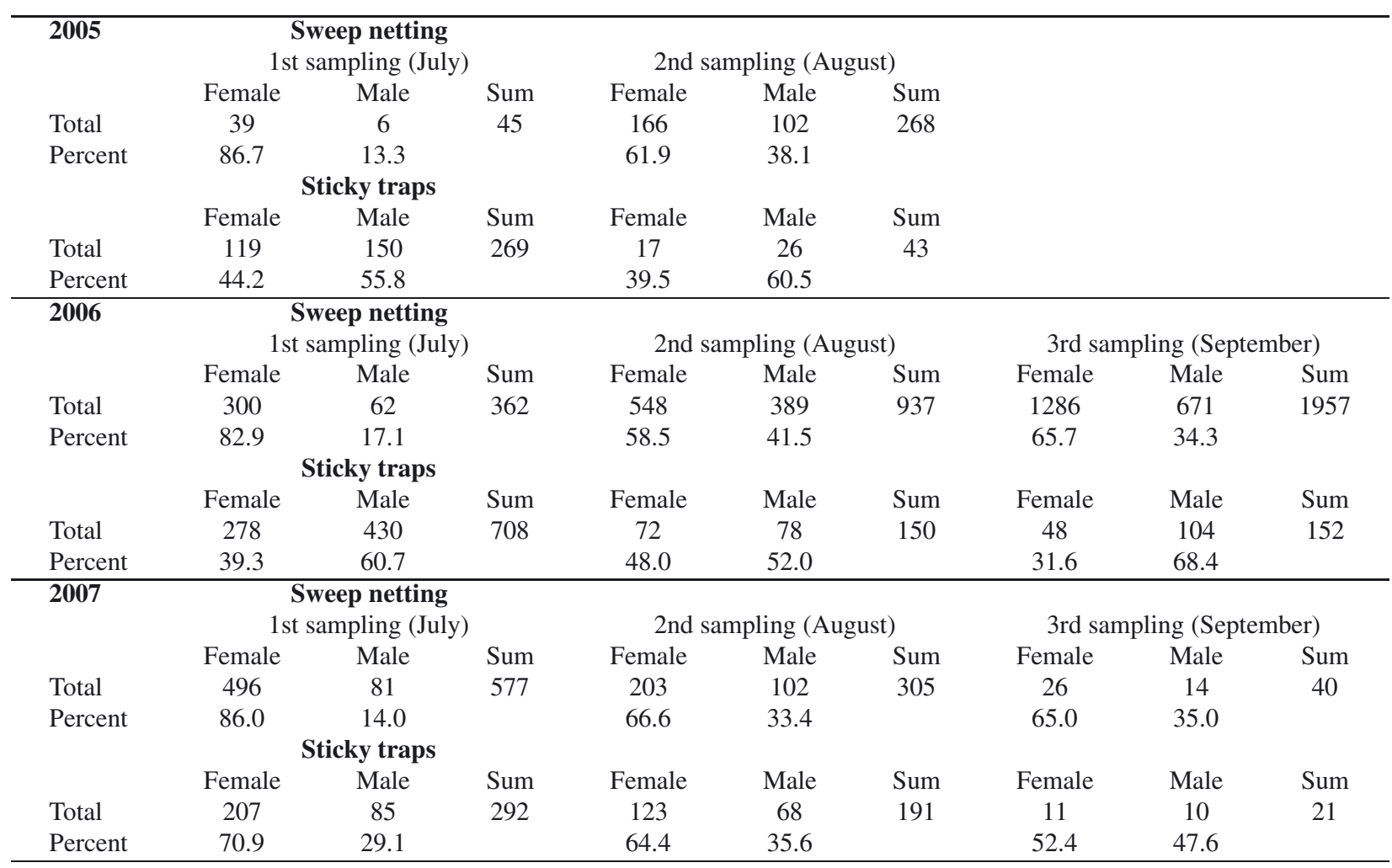


S. Rauschen et al.

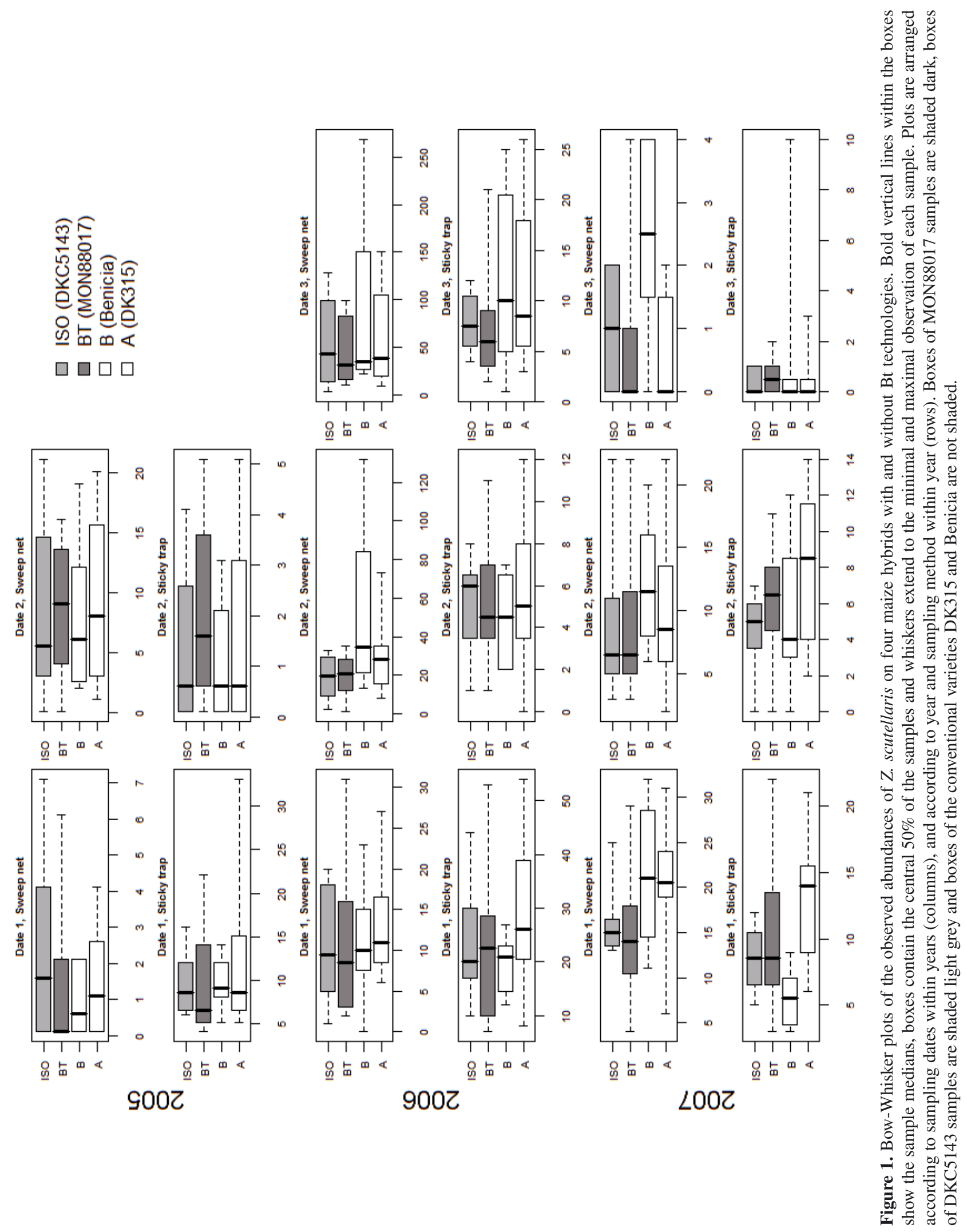


Generally, the maize leafhopper was more abundant in 2006 than in 2005. In 2007, fewer individuals than in the two previous years were caught, although in July a high abundance of $Z$. scutellaris was detected with the sweep nets (Fig. 1).

\section{Statistical analysis of Z. scutellaris data}

For each sampling date and method combination (i.e. 16 combinations) a generalized linear model (GLM) based on the count data was used to assess potential differences between the maize lines. Including soil parameters as covariates into the models, additional to the four varieties, reduced the residual deviance by up to $62 \%$. However, the different models contained from 1 up to 9 different covariates, and there were no consistent patterns after Akaike information criterion (AIC) selection, neither in occurrence of covariates nor in the sign of the estimated coefficients. Hence, because of the lack of a clear and interpretable relationship between the measured soil parameters as covariates and Z. scutellaris abundance, the assessment of differences between the varieties was performed based on generalized linear models including only the block and the variety effects.

The $90 \%$ confidence intervals for all pairwise comparisons between maize cultivars for all occurring combinations of sampling date and sampling methods are shown in Figures 2, 3 and 4 for the 2005, 2006 and 2007 samplings, respectively. In each plot, the confidence interval for the comparison of major interest, DKc5143Bt MON88017 (BT) vs. DKc5143 (ISO) is drawn at the top. Additionally, drawn with black lines are the comparisons of MON88017 to the two conventional varieties. The confidence intervals of the comparisons among the untransformed lines DKc5143, Benicia and DK315 are drawn in light grey, because they are of secondary importance, i.e. serve to range in potential differences. In all of the considered cases, the data do not provide evidence for a significant difference (at a comparison wise $10 \%$ significance level) in mean abundance between DKc5143-Bt MON88017 and DKc5143; none of the presented confidence intervals excludes the value 1 . Moreover, the ratio of mean abundance between DKc5143Bt MON88017 and DKc5143 had a similar range as at least one of the comparisons among the three untransformed cultivars. Table 3 shows the point estimates and confidence bounds for the ratios of mean abundances in DKc5143-Bt MON88017 to the mean abundances in DKc5143 in numbers. There was a decrease in abundance in DKc5143-Bt MON88017 compared to DKc5143 that occurred in 2005 at date 1 and was recorded with sweep net sampling. Although the mean abundance observed in DKc5143-Bt MON88017 was 45\% of that observed in
DKc5143, the difference was not significant and a similar effect was not corroborated by the observations based on sticky traps on the same date. The largest increase in abundance of leafhoppers in DKc5143-Bt MON88017 over that in DKc5143 was observed in 2005 at date 2, recorded with sticky traps, were the abundance observed in DKc5143-Bt MON88017 was about 210\% of that observed in DKc5143. This effect is not significant, nor was it supported by net sampling.

Greater differences in the ratios of the mean abundances were observed in comparisons between the conventional cultivar lines DKc5143, DK315 and Benicia. In both 2006 (Fig. 3) and 2007 (Fig. 4), there were ratios between these cultivars where the confidence intervals do not include 1. Sweep netting data from the second sampling in 2006 (Fig. 3) and the first and third sampling in 2007 show that Benicia featured higher densities of Z. scutellaris than both DKc5143 and DK315.

\section{DISCUSSION}

\section{The plant- and leafhopper community}

The Auchenorrhyncha assemblage found in maize can be categorised into two groups, dwellers/ colonizers/residents or vagrants. The first group (dwellers/colonizers/residents) encompasses species that feed extensively on maize and complete at least part of their lifecycle on this host plant. The most notable representative of this group is the maize leafhopper Z. scutellaris, which has been reported from maize fields in different parts of Europe (Candolfi et al., 2004; Kiss et al., 2002; Pons et al., 2005; Rauschen et al., 2008; Schmitz and Bartsch, 2001). Moreover, exposure of Z. scutellaris to proteins from GE maize has been documented (Dutton et al., 2004; Obrist et al., 2006). Meissle and Romeis (2009) measured the internal concentration of Cry3Bb1 from MON88017 in Z. scutellaris with over $1 \mu \mathrm{g} . \mathrm{g}^{-1}$ dry weight. Other species in this group are E. atropunctata, $P$. alienus, M. laevis and E. pteridis which have been found in maize fields (Kiss et al., 2002; Rauschen et al., 2008). Some have been demonstrated to contain considerable amounts of Cry protein (Meissle and Romeis, 2009). These plant- and leafhoppers and especially Z. scutellaris can reasonably be used in non-target risk assessment. Predators and parasitoids that attack leafhoppers are exposed to Cry proteins when they attack $Z$. scutellaris which contain Cry proteins after feeding on maize with $B t$ traits.

The second group of Auchenorrhyncha consists of vagrants from off-crop furrows and ridges or the surrounding area under cultivation. These insects probably spend only little time in maize stands, while searching for a suitable host. Feeding on maize may occur, but is probably 
S. Rauschen et al.
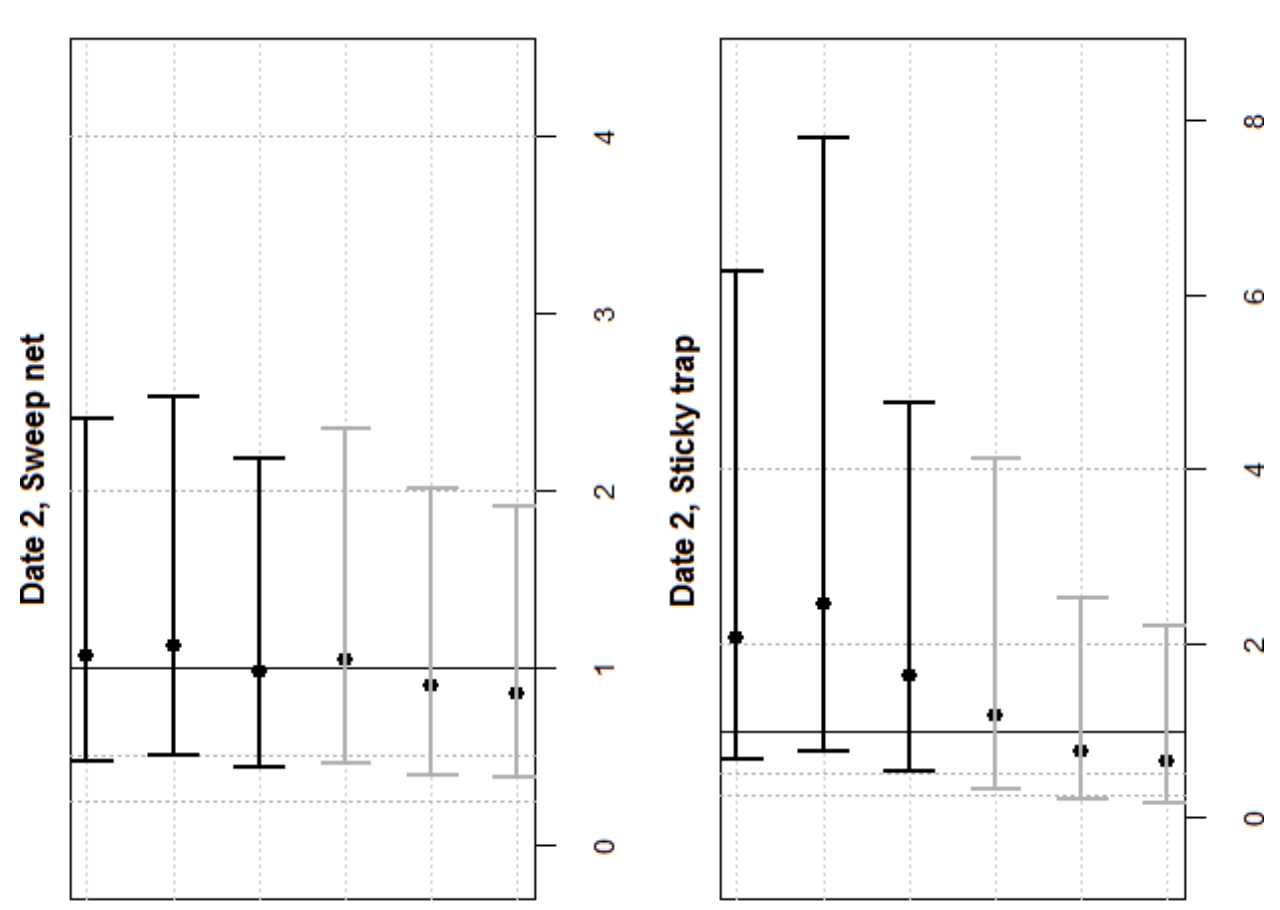

5
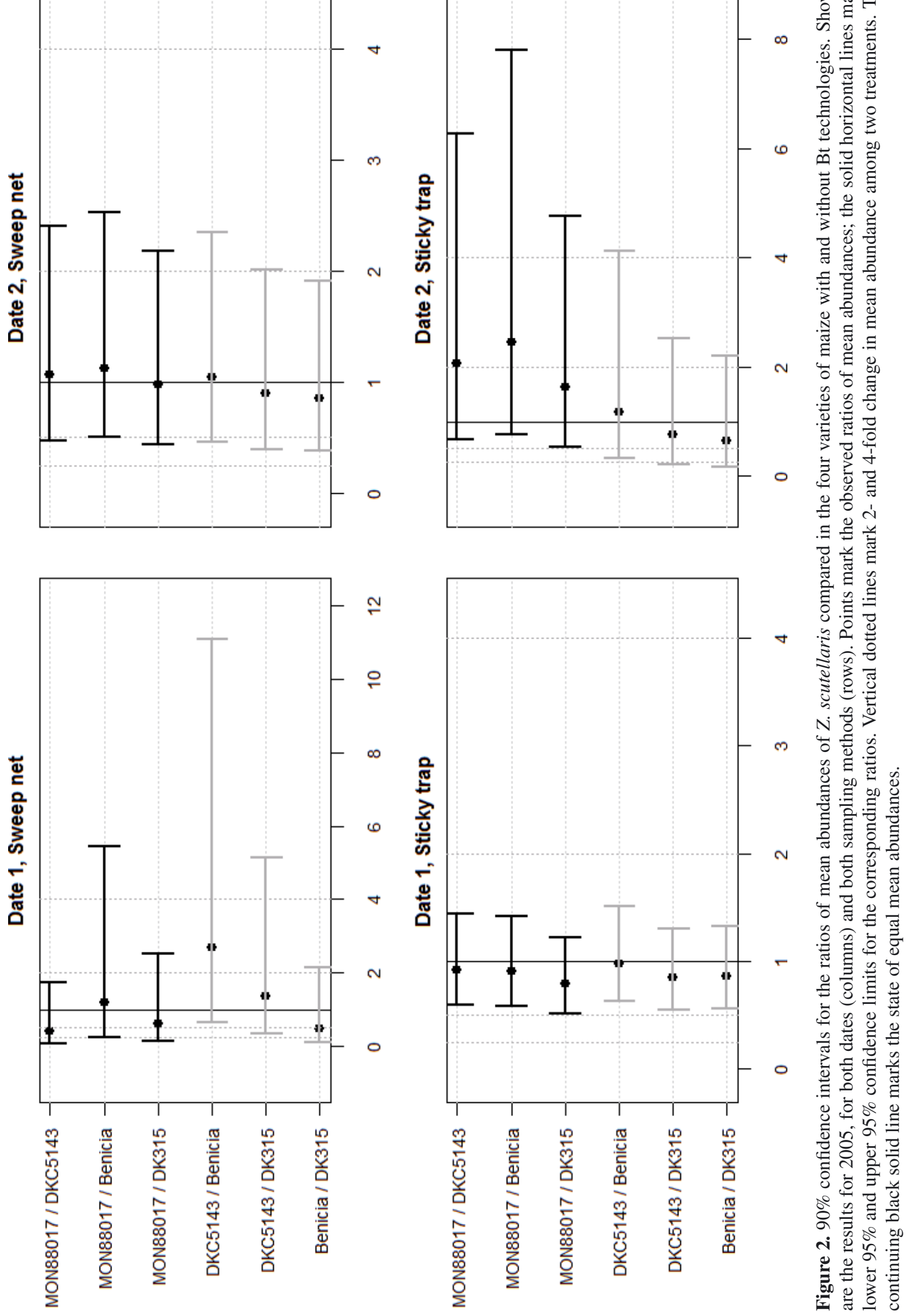

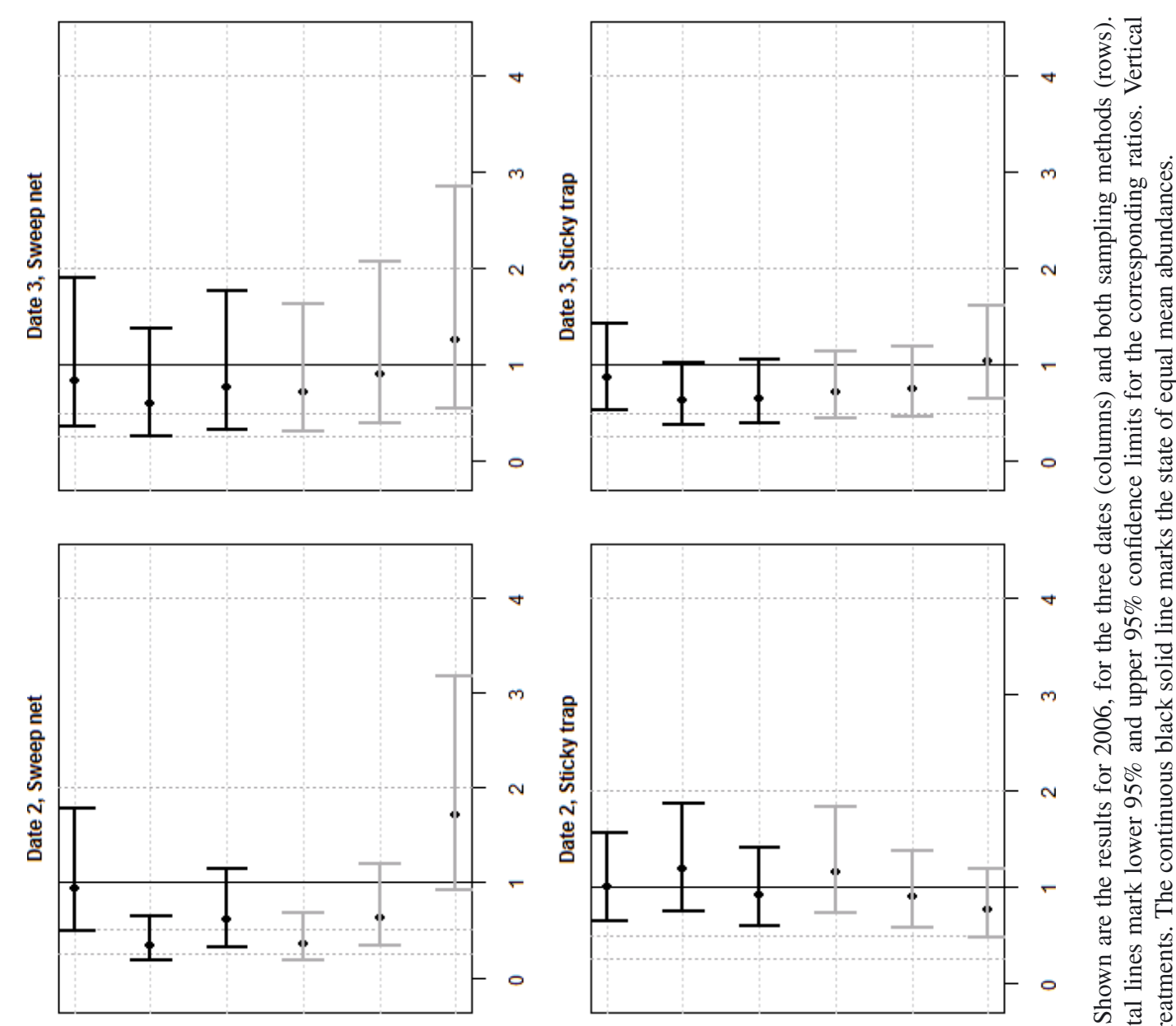

ज 호

政

辛家

ક

tᄒ

定

두

to do

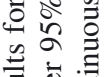

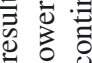

音
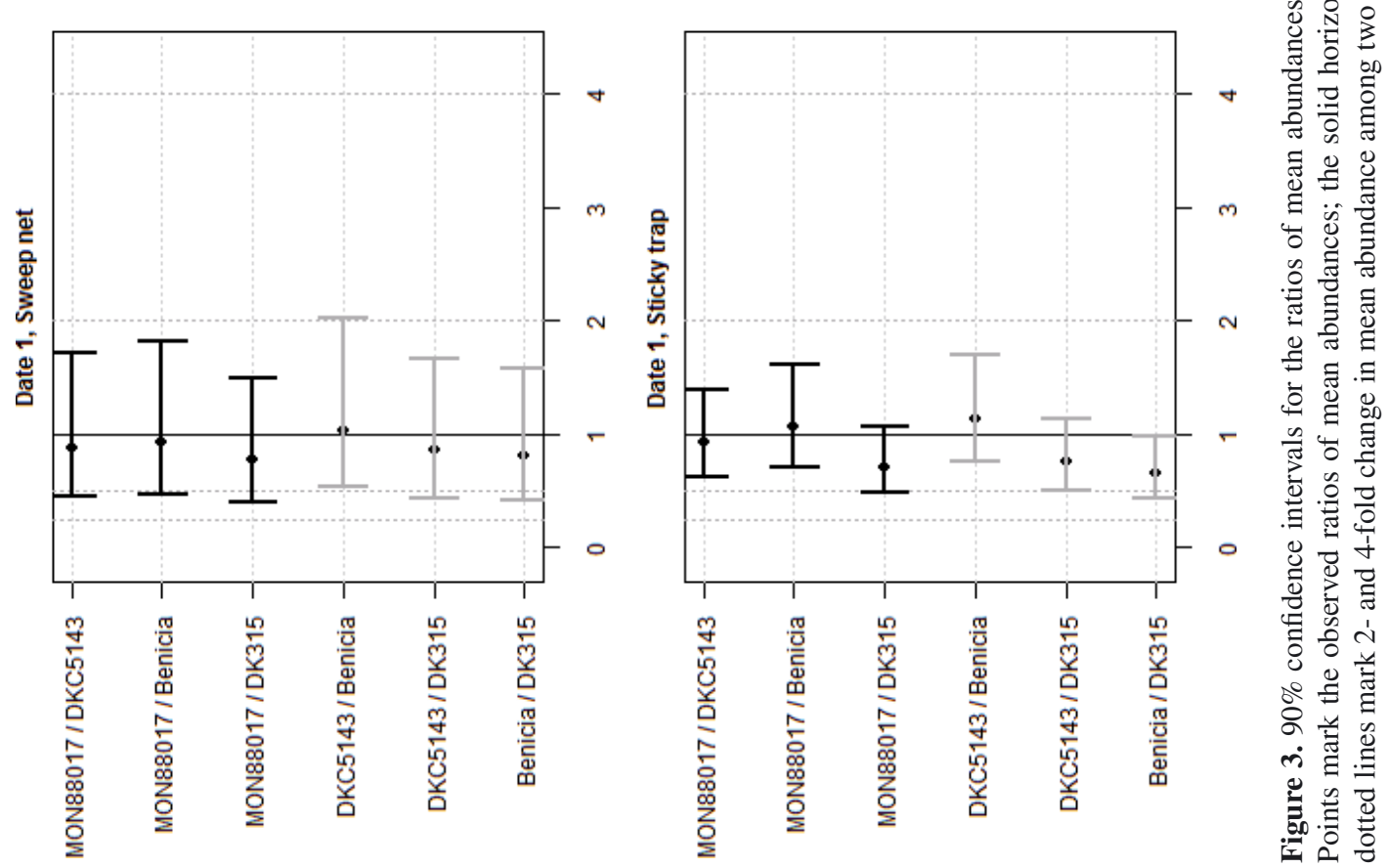
S. Rauschen et al.

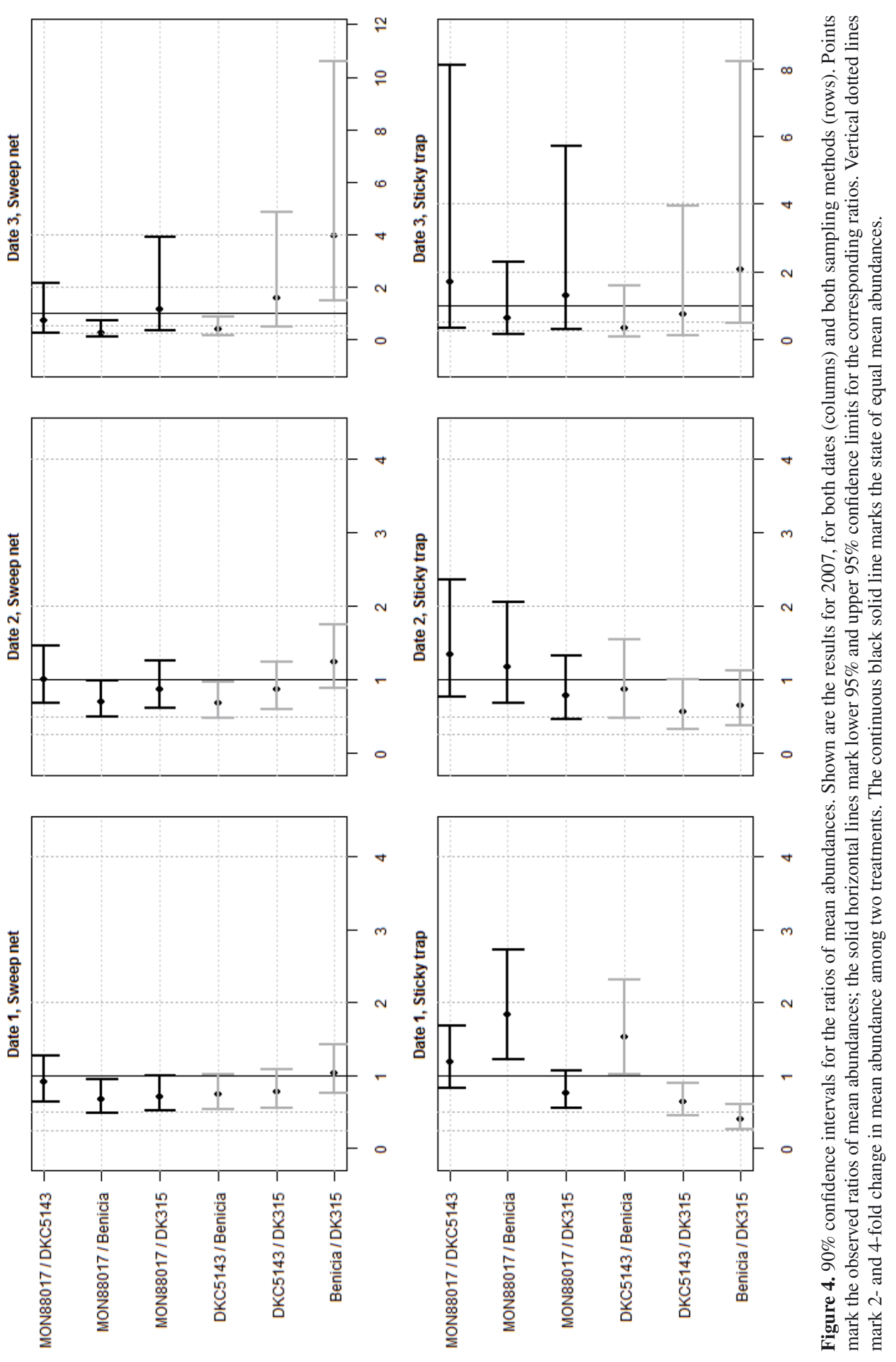


No impact of Bt-maize MON88017 on Zyginidia scutellaris densities

Table 3. Estimated ratios of mean abundances in Bt-maize DKc5143-Bt event MON88017 relative to the near-isogenic DKc5143 and the lower and upper limits of the corresponding $90 \%$ confidence intervals, for each combination of year, sampling method and sampling date.

\begin{tabular}{cccccc}
\hline Year & Date & Method & Estimate & 95\% lower confidence limit & 95\% upper confidence limit \\
\hline 2005 & 1 & Sweep net & 0.45 & 0.11 & 1.77 \\
2005 & 1 & Sticky trap & 0.94 & 0.60 & 1.45 \\
2005 & 2 & Sweep net & 1.08 & 0.49 & 2.41 \\
2005 & 2 & Sticky trap & 2.08 & 0.68 & 6.30 \\
2006 & 1 & Sweep net & 0.90 & 0.47 & 1.74 \\
2006 & 1 & Sticky trap & 0.94 & 0.63 & 1.40 \\
2006 & 2 & Sweep net & 0.95 & 0.51 & 1.80 \\
2006 & 2 & Sticky trap & 1.02 & 0.67 & 1.58 \\
2006 & 3 & Sweep net & 0.85 & 0.38 & 1.92 \\
2006 & 3 & Sticky trap & 0.88 & 0.54 & 1.44 \\
2007 & 1 & Sweep net & 0.92 & 0.66 & 1.29 \\
2007 & 1 & Sticky trap & 1.19 & 0.84 & 1.70 \\
2007 & 2 & Sweep net & 1.02 & 0.70 & 1.48 \\
2007 & 2 & Sticky trap & 1.36 & 0.77 & 2.37 \\
2007 & 3 & Sweep net & 0.75 & 0.26 & 2.16 \\
2007 & 3 & Sticky trap & 1.71 & 0.36 & 8.17 \\
\hline
\end{tabular}

limited and may not support the development or maintenance of larger populations. The 10 species that together accounted for $0.7 \%$ of individuals all belong to this group. These species likely used shrubs, trees and herbaceous undergrowth beyond the perimeter of maize around the experimental field. Others may have come from grassy field margins. Exposure to Cry proteins is unlikely for species in this group. The only two species that are exposed based on their feeding behaviour are P. spumarius and N. campestris. All other species are phloem feeders and will not be exposed to Cry proteins, since Cry proteins are regularly not found in the phloem sap of maize (Head et al., 2001; Raps et al., 2001). Therefore, the exposure of predaceous and parasitic insects to Cry proteins would be limited when feeding on vagrant species on maize.

\section{The field densities of the maize leafhopper}

Data could only be analysed for the most abundant leafhopper Z. scutellaris. There were no consistent differences in the densities of this species between plots with DKc5143-Bt MON88017 and plots planted with the near-isogenic line DKc5143. On two occasions there were more leafhoppers present in the $B t$-maize, while on one occasion there were more in the near-isogenic maize. The differences were smaller than those between the two conventional hybrid lines. There was, however, no consistent pattern with respect to the density of the maize leafhopper in these two conventional hybrids. At times there were more Z. scutellaris in DK315; at others, this species was more abundant in Benicia. It may be possible that these fluctuations are based on physiological differences between these hybrids and can be interpreted as a varietal effect, as recently reported for the plant bug Trigonotylus caelestialium (Heteroptera: Miridae) (Rauschen et al., 2009), possibly modulated by other factors.

The two sampling methods reflected the population density of Z. scutellaris differently. Sweep net samples caught large numbers of the maize leafhopper later in the season, while the opposite effect was seen with the sticky traps. The reason for this is unclear. Observations in the field implicate a different behaviour of $Z$. scutellaris as a possible reason. In the first part of the growing season, maize leafhoppers could be observed actively flying between the rows of maize plants, covering distances of some meters during a single flight (personal observation). This is consistent with leafhoppers colonising the maize field. Insects appeared to be in flight when trapped because their wings were spread (personal observation). Toward the end of the season, the predominant mode of locomotion was jumping over short distances (personal observation): Maize leafhoppers were observed landing on the sticky traps with their tarsi first, walking around on the glued surfaces and then jumping off again. Therefore, few insects were trapped, although their density in the field was very high, as evidenced by the sweep netting.

The two sampling methods were also conflictive in their detection of differences in the abundance of the 


\section{S. Rauschen et al.}

maize leafhopper in the four different maize hybrids. With the sweep nets, differences were detected between DK315 and Benicia in five cases over the three years, and in three cases between DKc5143-Bt MON88017 and the near-isogenic line. The sticky traps only showed one significant difference at one sampling date. Thus, the two methods are not consistent in the representation of fieldpopulations of Z. scutellaris and of distribution patterns of this species in different maize cultivars. Both data from sweep net catches and sticky traps can be used to assess the presence and density of plant- and leafhoppers in maize, but with certain limitations. The development of the field population of $Z$. scutellaris can be monitored closely by sweep netting as sticky traps failed to detect the increase in density over the growing season. For a reliable quantification of leafhopper abundance, sweep netting should be conducted along with direct observations in the field. For determining the presence or absence of plant- and leafhoppers, sticky traps are most valuable, since they can be used over long periods of time without great expenses and effort. Flight activity can be estimated based on caught numbers of leafhoppers, but the field densities of $Z$. scutellaris are underestimated. The methods may complement each other but sticky traps should not be used exclusively.

The data show an absence of a discernible impact of $B t$-event MON88017 on the field densities of the maize leafhopper Z. scutellaris. Differences between the maize cultivars existed in terms of this species' density, but were inconsistent over the years. This leads to the conclusion, that the maize DKc5143-Bt event MON88017 poses negligible risk to these arthropods. Little is known about the biological control of this herbivore group in maize either by generalist predators or by specialised parasitoids. Their role in the general surveillance of generic biological control function in maize therefore remains unclear, but could be investigated further using the methods employed in this study.

\section{MATERIALS AND METHODS}

\section{Genetically engineered plant material}

The GE variety used in the field release experiment was the Bt-maize DKc5143-Bt (event MON88017; Monsanto Company, St. Louis, Missouri, USA). Plants of this maize variety contain a transgenic cassette with two genes: one encoding for a variant of the Bacillus thuringiensis kumamotoensis Coleopteran active Cry3Bb1 protein directed against the Western corn rootworm (trademark YieldGard ${ }^{\circledR}$ Rootworm), and another for the Agrobacterium sp. strain CP4 5-enolpyruvylshikimate3-phosphate synthase (CP4 EPSPS), which confers tolerance against glyphosate, the active ingredient of the herbicide Roundup (trademark Roundup Ready ${ }^{\circledR}$ ) $\left(\mathrm{AGBIOS}^{5}\right.$ ). DNA Recombination in maize cells was performed by the Agrobacterium mediated transfer of the plasmid vector PV-ZMIR39 (McCann et al., 2007).

\section{Experimental design}

Within an area of approximately 4 ha four different maize lines were planted in a randomised complete block design with eight replicates each, at a site near Würzburg in Lower Frankonia (Germany). Apart from $B t$-maize DKc5143-Bt (event MON88017, BT) and its near isogenic line DKc5143 (ISO; both Monsanto Co., St. Louis, Missouri, USA) two conventional maize lines, Benicia (Pioneer HiBred, Johnston, Iowa, USA) and DK315 (Monsanto Co.), were used for the experiment. Seeds were supplied by the respective breeders. Individual plots measured 40.5 by $31.5 \mathrm{~m}$ ( $0.13 \mathrm{ha})$ and contained 42 maize rows with $75 \mathrm{~cm}$ distance between them and $15 \mathrm{~cm}$ between individual neighbouring plants. The plots were aligned in four parallel columns of eight plots each, with a $4.5 \mathrm{~m}$ wide clearance between neighbouring rows of plots for easy access. The experimental field was surrounded by a $4.5 \mathrm{~m}$ clearance strip followed by a $10 \mathrm{~m}$ wide perimeter of conventional maize (Gavott, KWS Saat, AG, Einbeck, Germany). The experiment was performed in three successive years, whereby the location of the plots with their respective maize lines was identical to ensure similar abiotic parameters. The field was planted on May 27 (calendar week CW 21) in 2005, on May 9 (CW 19) in 2006 and on May 21 (CW 21) in 2007. In 2005, a mixture of 0.8 L Motivell (BASF AG, Ludwigshafen, Germany, active ingredient Nicosulfuron at 40 g. $\mathrm{L}^{-1}$ ), $0.8 \mathrm{~L}$ Spectrum (BASF AG, active ingredient Dimethenamid-p at 720 g.L $\mathrm{L}^{-1}$ ) and $2.0 \mathrm{~L}$ Artett (BASF SE, active ingredients Terbuthylazine at 150 g.L. ${ }^{-1}$ and Bentazon 150 g.. $\mathrm{L}^{-1}$ ) were used to control weeds during the 2 to 8 leaf stage. In 2006 and 2007, a mixture of 3.0 L Gardo Gold (Syngenta Co., Basel, Switzerland, active ingredients S-Metolachlor at 312.5 g.L $\mathrm{L}^{-1}$ and Terbuthylazine at $187.5 \mathrm{~g} . \mathrm{L}^{-1}$ ) and $0.8 \mathrm{~L}$ Callisto (Syngenta Co., active ingredient Mesotrione at 100 g. $\mathrm{L}^{-1}$ ) was used for this purpose.

\section{Sweep net sampling}

Transect-wise sweep net sampling (net diameter $40 \mathrm{~cm}$, mesh width $1.5 \mathrm{~mm}$ ) was carried out along the maize rows, between rows 5 and 6, 15 and 16, 25 and 26, and 35 and 36 in each plot. Beginning at approx. $5 \mathrm{~m}$ from the

${ }^{5}$ AGBIOS database, http://www.agbios.com/dbase.php, accessed June 2007. 
margin into the plot, to avoid edge effects, 30 large steps were made while holding the sweep net vertically in front of the chest at a height of approximately $90 \mathrm{~cm}$ above the ground. After each transect, captured insects were transferred into glass vials with 70\% ethanol. Sweep net sampling was done on July 13 and August 24 (CW 28 and 34 ) in 2005, on July 19, August 16 and September 6 (CW 29, 33 and 36) in 2006, and on July 18, August 14 and September 4 (CW 29, 33 and 36) in 2007. Collected specimens were identified in the laboratory under a binocular microscope using Biedermann and Niedringhaus (2004).

\section{Custom made sticky traps}

Sticky traps were constructed from bamboo sticks (length approx. $1.2 \mathrm{~m}$, diameter around $10 \mathrm{~mm}$ ), a rectangular wire frame and a clear office plastic folder $(300 \mathrm{~mm}$ by $240 \mathrm{~mm}$, DIN A4) that was slipped over the frame. The surfaces of the folder were covered with insect glue (Temmen GmbH, Hattersheim, Germany). One glue trap was placed approximately in the middle of each plot, the top of the folder reaching a height of around $1 \mathrm{~m}$ above ground. Traps were set up for one week during the time frame when plots were sampled with the sweep net. After this interval, the folders were covered with cling film, removed from the wire frame and stored frozen at $-20{ }^{\circ} \mathrm{C}$ until the Auchenorrhyncha were carefully detached from the glued surfaces with a fine needle. The insects were transferred to Eppendorf tubes with $70 \%$ ethanol.

\section{Statistical analyses}

The major objective of the study was the quantification of the effect of $B t$-maize on the relative densities of Auchenorrhyncha species, which was taken as an indicator for the functioning of biological control. In this respect, the comparison of arthropod densities between the Bt-maize DKc5143-Bt event MON88017 (BT) and the near-isogenic line DKc5143 (ISO) is of primary interest, as it highlights potential differences caused by the $B t$-protein. Additionally, in order to illustrate the range of density differences due to differing characteristics of different maize lines, the two conventional hybrids DK315 and Benicia were included, and all four maize lines were compared amongst each other. The densities of insects per plot ( $n=8$ per sampling date) were analysed separately for each sampling date and method using generalized linear models (GLM) with log link and assuming the negative binomial distribution (McCullagh and Nelder, 1989; Venables and Ripley, 2002) implemented in the R package MASS (Venables and Ripley, 2002) in R, version 2.7.2 (R Development Core Team, 2008). A parameter modelling the extra-Poisson variability of the counts was estimated from the data. In a first step, the abundance of a species in a given plot was expressed in a log-linear dependence of the block effects, the different maize varieties and different soil parameters that were measured at the field site (Rauschen et al., 2009), which together might characterise the habitat variability. The Akaike Information Criterion (AIC) was used to select relevant soil covariates for the models, using the forward-backward selection implemented in the R-package MASS.

In a second step, generalized linear models with loglink and negative binomial assumption were fitted including the block and variety effects only. Based on these model fits, all pairwise comparisons among the maize varieties were then performed. Shown are approximate 90\% confidence intervals for the ratios of mean abundances between the varieties (McCulloch and Searle, 2001). For the computation of confidence intervals in R, the package multcomp (Hothorn et al., 2007, 2008) was used. For more a more in-depth description of the rational of this procedure see Rauschen et al. (2010).

\section{ACKNOWLEDGEMENTS}

The authors thank the German Federal Ministry of Education and Research (BMBF) for financial support (grant 0313279) and the Bavarian State Research Center for Agriculture (LFL Bayern) for providing and maintaining the field site.

Received September 23, 2010; accepted December 11, 2010.

\section{REFERENCES}

Árpás K, Tóth F, Kiss J (2005) Foliage-dwelling arthropods in Bt-transgenic and isogenic maize: a comparison through spider web analysis. Acta Phytopathol. Entomol. Hung. 40: 347-353

Biedermann R, Niedringhaus R (2004) Die Zikaden Deutschlands. Bestimmungstafeln für alle Arten. Wissenschaftlich Akademischer Buchvertrieb Fründ, Scheeßel

Candolfi MP, Brown K, Grimm C, Reber B, Schmidli H (2004) A faunistic approach to assess potential side-effects of genetically modified Bt-corn on non-target arthropods under field conditions. Biocontrol. Sci. Techn. 14: 129-170

Dutton A, Obrist L, D’Alessandro M, Diener L, Müller M, Romeis J, Bigler F (2004) Tracking Bt-toxin in transgenic maize to assess the risks on non-target arthropods. IOBC/WPRS Bulletin 27: 57-63 
EFSA (2006) Guidance document of the scientific panel on genetically modified organisms for the risk assessment of genetically modified plants and derived food and feed. The EFSA Journal 99: 1-100

EU (2001) Directive 2001/18/EC of the European Parliament and of the Council of 12 March 2001 on the deliberate release into the environment of genetically modified organisms and repealing Council Directive 90/220/EEC. L 106/1 of $4 / 17 / 2001$

EU (2002) Council Decision of 3 October 2002 establishing guidance notes supplementing Annex VII to Directive 2001/18/EC of the European Parliament and of the Council on the deliberate release into the environment of genetically modified organisms and repealing Council Directive 90/220/EEC. L 280/27 of 10/18/2002

Glare TR, O'Callaghan M (2000) Bacillus thuringiensis: Biology, ecology and safety. Chichester, New York, Weinheim, Brisbane, Singapore, Toronto, John Wiley \& Sons Limited

Head G, Brown CR, Groth ME, Duan JJ (2001) Cry1Ab protein levels in phytophagous insects feeding on transgenic corn: implications for secondary exposure risk assessment. Entomol. Exp. Appl. 99: 37-45

Hothorn T, Bretz F, Westfall P, Heiberger RM (2007) Multcomp: simultaneous inference for general linear hypotheses. R package version 0.991-9

Hothorn T, Bretz F, Westfall P (2008) Simultaneous inference in general parametric models. Biometrical J. 50: 346-363

Hummel HE (2003) Introduction of Diabrotica virgifera virgifera into the Old World and its consequences: a recently acquired invasive alien pest species on Zea mays from North America. Comm. Agr. Appl. Biol. Sci. 68: 45-57

James C (2009) Global status of commercialized biotech/GM crops: 2009. ISAAA Briefs 41, ISAAA, Ithaca

Kiss J, Szentkirályi F, Tóth F, Szénási A, Kádár F, Árpás K, Szekeres D, Edwards CR (2002) Bt corn: impact on nontargets and adjusting to local IPM systems. In Lelley T, Balázs E, Tepfer M, eds, Ecological Impact of GMO Dissemination in Agro-Ecosystems Wien, Facultas, pp 157-172

Kiss J, Edwards CR, Berger HK, Cata P, Cean M, Cheek S, Derron J, Festic H, Furlan L, Igrc-Barcic J, Ivanova I, Lammers W, Omelyuta V, Princzinger G, Reynaud P, Sivcev I, Sivicek P, Urek G, Vahala O (2005) Monitoring of Western Corn Rootworm (Diabrotica virgifera virgifera LeConte) in Europe 1992-2003. In Vidal S, Kuhlmann U, Edwards CR, eds, Western Corn Rootworm: Ecology and Management, Wallingford, CABI Publishing, pp 29-39

McCann MC, Trujillo WA, Riordan SG, Sorbet R, Bogdanova NN, Sidhu RS (2007) Comparison of the forage and grain composition from insect-protected and glyphosate- tolerant MON88017 corn to conventional corn (Zea mays L.). J. Agric. Food Chem. 55: 4034-4042

McCullagh P, Nelder JA (1989) Generalized Linear Models. Boca Raton, Chapman \& Hall/CRC

McCulloch CE, Searle SR (2001) Generalized, Linear and Mixed Models. NewYork, John Wiley \& Sons Inc

Meissle M, Romeis J (2009) The web-building spider Theridion impressum (Araneae: Theridiidae) is not adversely affected by $B t$ maize resistant to corn rootworms. Plant Biotech. J. 7: 645-656

Miller N, Estoup A, Toepfer S, Bourguet D, Lapchin L, Derridj S, Kim KS, Reynaud P, Furlan L, Guillemaud T (2005) Multiple transatlantic introductions of the Western Corn Rootworm. Science 310: 992

Nickel H (2003) The Leafhoppers and Planthoppers of Germany (Hemiptera, Auchenorrhyncha), patterns and strategies in a highly diverse group of phytophagous insects. Sofia, Moscow, Pensoft Series Faunistica

Obrist LB, Dutton A, Albajes R, Bigler F (2006) Exposure of arthropod predators to Cry1Ab toxin in Bt maize fields. Ecol. Entomol. 31: 143-154

Pons X, Lumbierres B, López C, Albajes R (2005) Abundance of non-target pests in transgenic Bt-maize: a farm scale study. Eur. J. Entomol. 102: 73-79

R Development Core Team (2008) R: A language and environment for statistical computing. R Foundation for Statistical Computing. Vienna, http://www.R-project.org

Raps A, Kehr J, Gugerli P, Moar WJ, Bigler F, Hilbeck A (2001) Immunological analysis of phloem sap of Bacillus thuringiensis corn and of the nontarget herbivore Rhopalosiphum padi (Homoptera: Aphididae) for the presence of Cry1Ab. Mol. Ecol. 10: 525-533

Rauschen S, Eckert J, Schaarschmidt F, Schuphan I, Gathmann A (2008) An evaluation of methods for assessing the impacts of $B t$-maize MON810 cultivation and pyrethroid insecticide use on Auchenorrhyncha (Planthoppers and Leafhoppers). Agric. For. Entomol. 10: 331-339

Rauschen S, Schultheis E, Pagel-Wieder S, Schuphan I, Eber S (2009) Impact of Bt-corn MON88017 in comparison to three conventional lines on Trigonotylus caelestialium (Kirkaldy) (Heteroptera: Miridae) field densities. Trans. Res. 18: $203-214$

Rauschen S, Schaarschmidt F, Gathmann A (2010) Occurrence and field densities of Coleoptera in the maize herb layer: Implications for Environmental Risk Assessment of genetically modified Bt-maize. Trans. Res. 19: 727-744

Romeis J, Meissle M, Bigler F (2006) Transgenic crops expressing Bacillus thuringiensis toxins and biological control. Nat. Biotechnol. 24: 63-71 
Romeis J, Bartsch D, Bigler F, Candolfi MP, Gielkens MMC, Hartley SE, Hellmich RL, Huesing JE, Jepson PC, Layton R, Quemada H, Raybould A, Rose RI, Schiemann J, Sears MK, Shelton AM, Sweet J, Vaituzis Z, Wolt JD (2008) Assessment of risk of insect-resistant transgenic crops to nontarget arthropods. Nat. Biotechnol. 26: 203-208

Sanvido O, Widmer F, Winzeler M, Bigler F (2005) A conceptual framework for the design of environmental postmarket monitoring of genetically modified plants. Environ. Biosafety Res. 4: 13-27

Sanvido O, Romeis J, Bigler F (2009) An approach for post-market monitoring of potential environmental effects of
Bt-maize expressing Cry1Ab on natural enemies. J. Appl. Entomol. 133: 236-248

Schmitz G, Bartsch D (2001) Biozönotische Untersuchungen in Maisfeldern bei Bonn und Aachen. Mitt. Dtsch. Ges. Allg. Angew. Entomol. 13: 615-618 (in German)

Schnepf E, Crickmore N, van Rie J, Lereclus D, Baum J, Feitelson F, Zeigler DR, Dean DH (1998) Bacillus thuringiensis and its pesticidal crystal proteins. Microbiol. Mol. Biol. R. 62: 775-806

Venables WN, Ripley BD (2002) Modern applied statistics with S. Fourth Edition. New York, Springer 